Original Research Paper

\title{
The Effect of Various Inclusion Levels of $\beta$-Mannanase on Nutrient Digestibility in Diets Consisting of Corn, Soybean Meal and Palm Kernel Expellers Fed to Growing Pigs
}

\author{
${ }^{1}$ Kwon, W.B., ${ }^{2}$ S.K. Park, ${ }^{1}$ C. Kong and ${ }^{1}$ B.G. Kim \\ ${ }^{I}$ Department of Animal Science and Technology, Konkuk University, Seoul, Republic of Korea \\ ${ }^{2}$ Animal Nutrition and Physiology Team, National Institute of Animal Science, \\ Rural Development Administration, Suwon, Republic of Korea
}

Article history

Received: 09-07-2014

Revised: 13-10-2014

Accepted: 20-10-2014

Corresponding Author:

B.G. Kim

Department of Animal Science and Technology, Konkuk

University, Seoul, Republic of Korea

E-mail: bgkim@konkuk.ac.kr

\begin{abstract}
An experiment was conducted to determine the effects of various inclusion levels of $\beta$-mannanase on the energy and mannan digestibility in diets containing corn, Soybean Meal (SBM) and Palm Kernel Expellers (PKE) fed to growing pigs. The PKE contained 92.6\% dry matter, 4,417 kcal gross energy $\mathrm{kg}^{-1}, 4.02 \%$ ash and $31.3 \%$ mannan on an as-fed basis. Six barrows with an initial body weight of $41.4 \pm 1.7 \mathrm{~kg}$ were individually housed in metabolism crates equipped with a feeder and a nipple drinker. Pigs were randomly allotted to a $6 \times 6$ Latin square design with 6 dietary treatments and 6 periods. An experimental period consisted of a 4-d adaptation period and a 5-d collection period. Pigs were fed corn-SBMbased diets containing $15 \%$ PKE with $0,400,800,1,600,2,400$ or 3,200 $\mathrm{U} \mathrm{kg}^{-1}$ of $\beta$-mannanase. A chromic oxide was added as an indigestible marker for fecal collection according to a marker-to-marker procedure. Urine was also collected from each period. Each of the 6 diets contained $3.60,3.91,4.06,2.57,3.57$ and $2.59 \%$ of mannan, respectively. No linear and quadratic effects of $\beta$-mannanase supplementation on apparent total tract digestibility of energy were observed. The digestibility of mannan was also not affected by the increasing level of $\beta$-mannanase supplementation. In conclusion, exogenous $\beta$-mannanase did not affect the energy and mannan digestibility in corn-SBM-based diets containing $15 \%$ of PKE fed to growing pigs.
\end{abstract}

Keywords: $\beta$-Mannanase, Palm Kernel Expellers, Pigs

\section{Introduction}

Dietary mannan, one of Non-Starch Polysaccharides (NSP), has negative effects on swine performance (Rainbird et al., 1984). Studies have been reported that $\beta$ mannanase supplementation to corn-Soybean Meal (SBM)-based diets affects nutrient digestibility and growth performance in pigs (Pettey et al., 2002; Lv et al., 2013). Palm Kernel Expellers (PKE) has recently received great attention because of the low price compared with other ingredients (Kim et al., 2001; Fang et al., 2007; Son et al., 2012). However, the content of mannan in PKE was much greater than that in other ingredients widely used for swine diets (Table 1; Mok et al., 2013).
Table 1. Nutrient composition of corn, Soybean Meal (SBM) and Palm Kernel Expellers (PKE; as-fed basis)

\begin{tabular}{lrrr}
\hline & Ingredient & & \\
\cline { 2 - 4 } Item (\%) & Corn & SBM & PKE \\
\hline Dry matter & 86.30 & 87.30 & 92.60 \\
Crude protein & 6.85 & 46.90 & 16.90 \\
Ether extract & 3.45 & 1.14 & 6.74 \\
Ash & 1.43 & 6.12 & 4.02 \\
Neutral detergent fiber & 19.70 & 31.40 & 68.30 \\
Acid detergent fiber & 2.92 & 6.52 & 37.80 \\
Calcium & 0.04 & 0.23 & 0.28 \\
Phosphorus & 0.28 & 0.63 & 0.66 \\
Mannan & 0.29 & 1.20 & 31.30 \\
\hline
\end{tabular}


There is a possibility that the $\beta$-mannanase can be used more efficiently in the PKE-based diets due to abundant substrates. Enzyme complex of mannanase and cellulase effectively hydrolyzed the fiber components of PKE and the pretreating PKE with the enzyme complex resulted in improvement in the true metabolizable energy value of pre-treated PKE compared with the raw PKE in diets fed to broilers (Saenphoom et al., 2013). In pigs, $\beta$-mannanase improved apparent ileal and total tract digestibilities of Dry Matter (DM), organic matter and energy in diets containing $10 \%$ PKE fed to pigs (Mok et al., 2013). However, data on the dosedependent effects of $\beta$-mannanase on energy and mannan digestibility of PKE-containing diets are rare.

Therefore, the objective of present study was to determine the effects of various inclusion levels of $\beta$ mannanase on nutrient digestibility in diets consisting of corn, SBM and PKE fed to growing pigs.

\section{Materials and Methods}

\section{Animals and Experimental Design}

The experimental procedure was approved by the Institutional Animal Care and Use Committee at Konkuk University. Six crossbred barrows with an average initial body weight of $41.4 \mathrm{~kg}$ (standard deviation $=1.7$ ) were used to determine the effect of supplemental $\beta$ mannanase. Animals were allotted to a $6 \times 6$ Latin square design with 6 diets and 6 periods (Kim and Kim, 2010).
Pigs were individually housed in metabolism crates that were equipped with a feeder and a nipple drinker.

\section{Diets and Feeding}

Six experimental diets were corn-SBM-based diets containing $15 \%$ PKE with 6 concentrations of supplemental $\beta$-mannanase at $0,400,800,1,600,2,400$ or $3,200 \mathrm{U} \mathrm{kg}^{-1}$ of $\beta$-mannanase (Table 2). All diets were prepared in mash form. The exogenous carbohydrase, $\beta$ mannanase, was produced by Bacillus subtilis grown on Luria broth. The amount of feed provided daily per pig was calculated as approximately 3 times the estimated energy requirement for maintenance $\left(197 \mathrm{kcal} \mathrm{kg}^{-1}\right.$ body weight ${ }^{0.60}$; Kil et al., 2013).

Daily feed allowance was divided into 2 equal meals and fed to the pigs at 0900 and 1700 . Water was freely accessible at all times. Vitamins and minerals were included in all diets to meet or exceed nutrient requirement estimates (NRC, 2012).

\section{Sample Collection and Chemical Analysis}

An experimental period consisted of $9 \mathrm{~d}$. Feces were collected according to the marker-to-marker procedure (Kong and Adeola, 2014) during $5 \mathrm{~d}$ of the collection period after $4 \mathrm{~d}$ of the adaptation period. Chromic oxide was added as an indigestible marker to the morning diets on $\mathrm{d} 5$ and 10 . Urine was collected from 1400 on $\mathrm{d} 5$ to 1400 on $\mathrm{d} 10$. The feces and urine was immediately stored at $-20^{\circ} \mathrm{C}$ after collection.

Table 2. Ingredient composition and mannan content of experimental diets ${ }^{\mathrm{a}}$ (as-fed basis)

\begin{tabular}{|c|c|c|c|c|c|c|}
\hline \multirow[b]{2}{*}{ Item } & \multicolumn{6}{|c|}{$\beta$-Mannanase $\left(\mathrm{U} \mathrm{kg}^{-1}\right)$} \\
\hline & 0 & 400 & 800 & 1,600 & 2,400 & 3,200 \\
\hline \multicolumn{7}{|l|}{ Ingredient (\%) } \\
\hline Ground corn & 56.40 & 56.40 & 56.40 & 56.40 & 56.40 & 56.40 \\
\hline Soybean meal, $48 \%$ crude protein & 25.00 & 25.00 & 25.00 & 25.00 & 25.00 & 25.00 \\
\hline Palm kernel expellers & 15.00 & 15.00 & 15.00 & 15.00 & 15.00 & 15.00 \\
\hline L-Lysine $\cdot \mathrm{HCl}$ & 0.50 & 0.50 & 0.50 & 0.50 & 0.50 & 0.50 \\
\hline$\beta$-Mannanase & - & 0.05 & 0.10 & 0.20 & 0.30 & 0.40 \\
\hline$\beta$-Mannanase carrier & 0.40 & 0.35 & 0.30 & 0.20 & 0.10 & - \\
\hline Limestone & 1.00 & 1.00 & 1.00 & 1.00 & 1.00 & 1.00 \\
\hline Dicalcium phosphate & 0.80 & 0.80 & 0.80 & 0.80 & 0.80 & 0.80 \\
\hline Salt & 0.40 & 0.40 & 0.40 & 0.40 & 0.40 & 0.40 \\
\hline Vitamin-mineral premix ${ }^{b}$ & 0.50 & 0.50 & 0.50 & 0.50 & 0.50 & 0.50 \\
\hline Total & 100.00 & 100.00 & 100.00 & 100.00 & 100.00 & 100.00 \\
\hline \multicolumn{7}{|l|}{ Analyzed composition (\%) } \\
\hline Mannan & 3.60 & 3.91 & 4.06 & 2.57 & 3.57 & 2.59 \\
\hline
\end{tabular}

${ }^{a}$ All diets were formulated to contain $3,213 \mathrm{kcal}$ metabolizable energy $\mathrm{kg}^{-1}, 19.6 \%$ crude protein, $1.18 \%$ Standardized Ileal Digestible (SID) lysine, $0.51 \%$ SID methionine + cysteine, $0.56 \%$ threonine, $0.19 \%$ tryptophan, $0.69 \%$ calcium and $0.31 \%$ standardized total tract digestible phosphorus; ${ }^{b}$ Provided per kg of diet: Vitamin A, 11,128 IU; vitamin $\mathrm{D}_{3}, 2,204$ IU; vitamin E, 66 $\mathrm{IU}$; vitamin K, $1.42 \mathrm{mg}$; thiamin, $0.24 \mathrm{mg}$; riboflavin, $6.58 \mathrm{mg}$; pyridoxine, $0.24 \mathrm{mg}$; vitamin $\mathrm{B}_{12}, 0.03 \mathrm{mg}$; D-pantothenic acid, 23.5 $\mathrm{mg}$; niacin, $44 \mathrm{mg}$; folic acid, $1.58 \mathrm{mg}$; biotin, $0.44 \mathrm{mg}$; Cu, $10 \mathrm{mg}$ as copper sulfate; Fe, $125 \mathrm{mg}$ as iron sulfate; I, $1.26 \mathrm{mg}$ as potassium iodate; $\mathrm{Mn}, 60 \mathrm{mg}$ as manganese sulfate; Se, $0.3 \mathrm{mg}$ as sodium selenite; $\mathrm{Zn}, 100 \mathrm{mg}$ as zinc oxide 
Table 3.Effects of various inclusion levels of $\beta$-mannanase on energy digestibility in corn-soybean meal-palm kernel expeller-based diets fed to growing pigs ${ }^{\mathrm{a}, \mathrm{b}}$ (as-fed basis)

\begin{tabular}{|c|c|c|c|c|c|c|c|c|c|}
\hline \multirow[b]{2}{*}{ Item $^{\mathrm{c}}$} & \multicolumn{6}{|c|}{$\beta$-Mannanase $\left(\mathrm{U} \mathrm{kg}^{-1}\right)$} & \multirow[b]{2}{*}{ SEM $^{\mathrm{d}}$} & \multicolumn{2}{|c|}{ P-value } \\
\hline & 0 & 400 & 800 & 1,600 & 2,400 & 3,200 & & Linear & Quadratic \\
\hline Diet intake $\left(\mathrm{kg} 5\right.$ days $\left.^{-1}\right)$ & 9.71 & 9.64 & 9.60 & 9.72 & 9.52 & 9.47 & 0.58 & 0.07 & 0.55 \\
\hline GE intake (Mcal 5 days $^{-1}$ ) & 38.7 & 38.8 & 38.8 & 39.3 & 38.4 & 38.0 & 2.35 & 0.12 & 0.09 \\
\hline Fecal GE output (Mcal 5 days $^{-1}$ ) & 6.71 & 6.53 & 7.00 & 6.74 & 6.72 & 6.47 & 0.32 & 0.36 & 0.14 \\
\hline ATTD of energy $(\%)$ & 82.5 & 83.0 & 81.8 & 82.8 & 82.3 & 82.9 & 0.67 & 0.79 & 0.49 \\
\hline $\mathrm{DE}$ in $\operatorname{diet}\left(\mathrm{kcal} \mathrm{kg}^{-1}\right)$ & 3,290 & 3,345 & 3,312 & 3,345 & 3,325 & 3,323 & 27.00 & 0.50 & 0.21 \\
\hline Urinary GE output (Mcal 5 days $^{-1}$ ) & 1.24 & 1.23 & 1.14 & 1.11 & 0.97 & 1.07 & 0.13 & 0.05 & 0.38 \\
\hline ME in diet $\left(\mathrm{kcal} \mathrm{kg}^{-1}\right)$ & 3,163 & 3,217 & 3,192 & 3,232 & 3,221 & 3,208 & 28.00 & 0.19 & 0.14 \\
\hline
\end{tabular}

${ }^{\mathrm{a}}$ Each least squares mean represents 6 observations except a diet containing $2,400 \mathrm{U} \mathrm{kg}^{-1}$ of $\beta$-mannanase (5 observations); ${ }^{\mathrm{b}} \mathrm{Diet}$ intake, GE intake, fecal GE output and urinary GE output were based on $5 \mathrm{~d}$ of collection; ${ }^{\mathrm{c}} \mathrm{GE}=\mathrm{Gross}$ Energy; $\mathrm{DE}=\mathrm{Digestible}$ Energy; ATTD = Apparent Total Tract Digestibility; ME = Metabolizable Energy; ${ }^{\mathrm{d}} \mathrm{SEM}=$ Standard Error of the Means

Table 4. Effects of various inclusion levels of $\beta$-mannanase on the mannan digestibility in corn-soybean meal-palm kernel expellerbased diets fed to pigs ${ }^{\mathrm{a}, \mathrm{b}}$ (as-fed basis)

\begin{tabular}{|c|c|c|c|c|c|c|c|c|c|}
\hline \multirow[b]{2}{*}{ Item } & \multicolumn{6}{|c|}{$\beta$-Mannanase $\left(\mathrm{U} \mathrm{kg}^{-1}\right)$} & \multirow[b]{2}{*}{ SEM $^{\mathrm{b}}$} & \multicolumn{2}{|c|}{ P-value } \\
\hline & 0 & 400 & 800 & 1,600 & 2,400 & 3,200 & & Linear & Quadratic \\
\hline Mannan intake (g 5 days $\left.^{-1}\right)$ & 329.0 & 326.0 & 325.0 & 329.0 & 322.0 & 320.0 & 20.0 & 0.07 & 0.55 \\
\hline Mannan output (g 5 days $^{-1}$ ) & 21.8 & 22.1 & 27.2 & 29.5 & 21.0 & 31.0 & 7.3 & 0.08 & 0.86 \\
\hline Mannan digestibility (\%) & 93.8 & 93.6 & 92.0 & 91.5 & 94.1 & 90.9 & 1.8 & 0.08 & 0.88 \\
\hline
\end{tabular}

${ }^{\mathrm{a}}$ Each least squares mean represents 6 observations except a diet containing $2,400 \mathrm{U} \mathrm{kg}^{-1}$ of $\beta$-mannanase (5 observations); ${ }^{\mathrm{b}} \mathrm{Mannan}$ intake and output were based on $5 \mathrm{~d}$ of collection; ${ }^{\mathrm{c}} \mathrm{SEM}=$ Standard Error of the Means

Fecal samples were dried in a forced-air drying oven at $55^{\circ} \mathrm{C}$ and ground before analysis. The diets, feces and urine were analyzed for gross energy using a bomb calorimeter (Parr 1261; Parr Instruments Co., Moline, IL, USA). Ingredient samples were analyzed for DM, crude protein, ether extract, crude fiber, ash, calcium, phosphorus, neutral detergent fiber and acid detergent fiber (AOAC, 2005). Diets and ingredient samples were also analyzed for the mannan concentration. The samples were hydrolyzed using $72 \%$ (w/w) $\mathrm{H}_{2} \mathrm{SO}_{4}$ for 1 h. Then, the samples were diluted with distilled water to $\mathrm{H}_{2} \mathrm{SO}_{4}$ concentration to $1 \mathrm{~N}$ and incubated at $121^{\circ} \mathrm{C}$ for $45 \mathrm{~min}$. The mannan contents in hydrolysates were determined using an evaporative light scattering detector and a Shodex sugar column SP0810 $(8.0 \times 300$ mm; Mok et al., 2013).

\section{Calculations and Statistical Analysis}

The contents of digestible energy and metabolizable energy in experimental diets were calculated by the procedures described by Kong and Adeola (2014). The mannan digestibility was calculated based on the mannan intake and output:

Mannan digestibility $(\%)=($ Md-Mf $) / \mathrm{Md} \times 100$ where, Md is the total mannan intake $(\mathrm{g})$ during collection period (from d 5 to 9 ) and Mf is the total fecal mannan output (g) during collection period (from d 5 to 9 ).

Data were analyzed using the MIXED procedure of SAS (SAS Institute Inc., Cary, NC, USA). The model included dietary treatment as a fixed variable and animal and period as random variables. Orthogonal polynomial contrasts were used to determine linear and quadratic effects of the supplemental $\beta$ mannanase concentrations.

The experimental unit was a pig and significance was determined at an $\alpha$ of 0.05 .

\section{Results}

During the fifth period, one pig fed the diet containing 2,400 $\mathrm{U} \mathrm{kg}^{-1} \beta$-mannanase had diarrhea and was excluded from the experiment. All other pigs were healthy throughout the experimental period.

The effects of various inclusion levels of $\beta$ mannanase on energy digestibility in corn-SBM-PKEbased diets fed to growing pigs are shown in Table 3.

There was no linear and quadratic effect on the Apparent Total Tract Digestibility (ATTD) of energy among the experimental treatments. However, the urinary GE output linearly decreased $(p<0.05)$ by the increasing level of $\beta$-mannanase supplementation. 
No diffferences were observed for the mannan digestibility among the various inclusion levels of $\beta$ mannanase in the experimental diets (Table 4).

\section{Discussion}

The PKE is a rich source of NSP components such as mannan and it contains about $31 \%$ of mannan which is greater than that of the corn and SBM used in this experiment (Table 1). Generally, the PKE contained 40 to $45 \%$ of NSP and 28 to $32 \%$ of mannan (Sundu et al., 2006; Mok et al., 2013). The analyzed value of mannan content in the PKE used in the present study is in agreement with previous studies.

In the present study, $15 \%$ of PKE was included in all experimental diets. Despite the experimental diets had enough substrates for the $\beta$-mannanase, no differences were observed for the energy digestibility of corn-SBMPKE-based diets with $\beta$-mannanase supplementation.

Mok et al. (2013) showed that the apparent ileal digestibility and ATTD of the DM and energy increased when $1,600 \mathrm{U} \mathrm{kg}^{-1}$ of $\beta$-mannnanase supplemented in the corn-SBM-based diets including $10 \%$ of PKE. These results are consistent with the study of Radcliffe et al. (1999) that reported increased the apparent ileal digestibility of DM and ATTD of energy for pigs fed corn-SBM-based diets with $0.5 \%$ of $\beta$-mannnanase addition. However, Pettey et al. (2002) found no effects of $\beta$-mannnanase on the DM and energy digestibility in pigs fed corn-SBM-based diets.

This inconsistency may be explained by the method for estimating digestibility. Mok et al. (2013) and Radcliffe et al. (1999) used the index method using the chromic oxide as an indigestible index for the estimation of digestibility, but Pettey et al. (2002) and this study used the total collection method for the feces and urine collections. The lack of response may be associated with potentially large variability in the index method.

An activity of exogenous carbohydrase may also be an issue on the energy digestibility study. Lower enzyme activity of exogenous carbohydrase in the gastrointestinal tract could become the reason for the lack of beneficial effect (Kim et al., 2004).

Mannan-endo-1,4- $\beta$-mannosidase, known as $\beta$ mannnanase is an "endo" acting enzyme that hydrolyzes mannan components of feedstuffs such as $\beta$-galactomannan and linear $\beta$-mannan (McCleary, 1988). The mannan can be degraded to mannanoligosaccharide or a small unit of sugar monomer such as mannose by the action of $\beta$-mannnanase.

However, only monosaccharides can be absorbed in the small intestine and the other metabolites such as mannan-oligosaccharide, mannotriose and mannobiose are not readily absorbed (Kong et al., 2011; NRC, 2012). In this study, it is possible that a relatively small quantity of mannose supplied energy to pigs than other experiments. For this reason, we could have found no effect of $\beta$-mannnanase supplementation regardless of the supplemental concentrations of $\beta$-mannanase.

However, only monosaccharides can be absorbed in the small intestine and the other metabolites such as mannan-oligosaccharide, mannotriose and mannobiose are not readily absorbed (Kong et al., 2011; NRC, 2012). In this study, it is possible that a relatively small quantity of mannose supplied energy to pigs than other experiments. For this reason, we could have found no effect of $\beta$-mannnanase supplementation regardless of the supplemental concentrations of $\beta$-mannanase.

Further research is required to clarify the action of $\beta$ mannanase on substrates in energy utilization and to determine the optimum inclusion level of $\beta$-mannanase when the mannan-rich ingredients are used in swine diets.

\section{Conclusion}

In this study, no effects of $\beta$-mannanase supplementation on energy or mannan digestibility of corn-SBM-based diet with $15 \%$ of PKE were observed.

\section{Funding Information}

The researchers are grateful for the support by Rural Development Administration (Suwon, Republic of Korea; PJ907038). This study resulted from the Konkuk University research support program.

\section{Author's Contributions}

W.B. Kwon: Conducted the animal experiment, summarized the data, and wrote most of the manuscript.

S.K. Park: Contributed to the animal experiment, the chemical analysis and manuscript preparation.

C. Kong: Reviewed statistical analysis procedures and provided important input in writing the manuscript.

B.G. Kim: Supervised the project and the preparation of the manuscript.

\section{Ethics}

The authors declare no ethical issues.

\section{References}

AOAC, 2005. Official methods of analysis of AOAC International. Association of Official Analytical Chemists. 
Fang, Z.F., J. Peng, Z.L. Liu and Y.G. Liu, 2007. Responses of non-starch polysaccharide-degrading enzymes on digestibility and performance of growing pigs fed a diet based on corn, soya bean meal and Chinese double-low rapeseed meal. J. Anim. Physiol. Anim. Nutr., 91: 361-368. DOI: $10.1111 / \mathrm{j} .1439-0396.2006 .00664 . \mathrm{x}$

Kil, D.Y., B.G. Kim and H.H. Stein, 2013. Invited review: Feed energy evaluation for growing pigs. Asian Austr. J. Anim. Sci., 26: 1205-1217. DOI: 10.5713/ajas.2013.r.02

Kim, B.G. and T.M. Kim, 2010. A program for making completely balanced Latin square designs employing a systemic method. Revista Colombiana de Ciencias Pecuarias, 23: 277-282.

Kim, B.G., J.H. Lee, H.J. Jung, Y.K. Han and K.M. Park et al., 2001. Effect of partial replacement of soybean meal with palm kernel meal and copra meal on growth performance, nutrient digestibility and carcass characteristics of finishing pigs. Asian Austr. J. Anim. Sci., 14: 821-830.

Kim, B.G., J.Z. Tian, J.S. Lim, D.Y. Kil and H.Y. Jeon et al., 2004. Influences of Enzyme complex supplementation on growth, ileal and apparent fecal digestibility and morphology of small intestine in pigs. Asian Austr. J. Anim. Sci., 17: 1729-1735.

Kong, C. and O. Adeola, 2014. Invited review: Evaluation of amino acid and energy utilization in feedstuff for swine and poultry diets. Asian Austr. J. Anim. Sci., 27: 917-925. DOI: 10.5713/ajas.2014.r.02

Kong, C., J.H. Lee and O. Adeola, 2011. Supplementation of $\beta$-mannanase to starter and grower diets for broilers. Can. J. Anim. Sci., 91: 389-397. DOI: 10.4141/CJAS10066

Lv, J.N., Y.Q. Chen, X.J. Guo, X.S. Piao and Y.H. Cao et al., 2013. Effect of supplementation of $\beta$ mannanase in corn-soybean meal diets on performance and nutrient digestibility in growing pigs. Asian Austr. J. Anim. Sci., 26: 579-587. DOI: 10.5713/ajas.2012.12612

McCleary, B.V., 1988. $\beta$-mannanase. Meth. Enzymol., 160: 596-610. DOI: 10.1016/0076-6879(88)60174-1
Mok, C.H., J.H. Lee and B.G. Kim, 2013. Effects of exogenous phytase and $\beta$-mannanase on ieal and total tract digestibility of energy and nutrients in palm kernel expeller-containing diets fed to growing pigs. Anim. Feed Sci. Tech., 186: 209-213. DOI: 10.1016/j.anifeedsci.2013.10.008w

NRC, 2012. Nutrient Requirements of Swine. 11th Edn., National Academic Press, Washington, DC., USA. ISBN-10: 978-0-309-22423-9

Pettey, L.A., S.D. Carter, B.W. Senne and J.A. Shriver, 2002. Effects of beta-mannanase addition to corn-soybean meal diets on growth performance, carcass traits and nutrient digestibility of weanling and growing-finishing pigs. J. Anim. Sci., 80: 1012-1019. PMID: 12002307

Radcliffe, J.S., B.C. Robbins, J.P. Rice, R.S. Pleasant and E.T. Kornegay, 1999. The effects of Hemicell $^{\circledR}$ on digestibilities of minerals, energy and amino acids in pigs fitted with steered ileocecal valve cannulas and fed a low and high protein corn-soybean meal diet. J. Anim. Sci., 77: 197-197

Rainbird, A.L., A.G. Low and T. Zebrowska, 1984. Effect of guar gum on glucose and water absorption from isolated loops of jejunum in conscious growing pigs. Br. J. Nutr., 52: 489-498. PMID: 6093855

Saenphoom, P., J.B. Liang, Y.W. Ho, T.C. Loh and M. Rosfarizan, 2013. Effects of enzyme treated palm kernel expeller on metabolizable energy, growth performance, villus height and digesta viscosity in broiler chickens. Asian Australas. J. Anim. Sci., 26: 537-544. DOI: 10.5713/ajas.2012.12463

Son, A.R., S.Y. Ji and B.G. Kim, 2012. Digestible and metabolizable energy concentrations in copra meal, palm kernel meal and cassava root fed to growing pigs. J. Anim. Sci., 90: 140-142. DOI: $10.2527 /$ jas 53822

Sundu, B., A. Kumar and J. Dingle, 2006. Palm kernel meal in broiler diets: Effect on chiken performance and health. World's Poult. Sci. J., 62: 316-325. DOI: 10.1079/WPS2005100 